\title{
CANONICAL CORRELATIONS AMONG CHEMICAL, PHYSICAL AND MORPHOLOGICAL CHARACTERISTICS OF XARAÉS PALISADEGRASS UNDER ROTATIONAL GRAZING
}

\author{
Renata La Guardia Nave ${ }^{1}$; Carlos Guilherme Silveira Pedreira ${ }^{2 *}$; César Gonçalves de Lima ${ }^{3}$ \\ ${ }^{1}$ USP/ESALQ - Programa de Pós-Graduação em Ciência Animal e Pastagens. \\ ${ }_{3}^{2}$ USP/ESALQ - Depto. de Zootecnia, C.P. 09 - 13418-900 - Piracicaba, SP - Brasil. \\ ${ }^{3}$ USP/FZEA - Depto. de Ciências Básicas, C.P. 23 - 13635-900 - Pirassununga, SP - Brasil. \\ *Corresponding author <cgspedre@esalq.usp.br>
}

\begin{abstract}
In forage evaluation experiments, the assessment of adaptive and productive characteristics of genotypes is generally prioritized over qualitative responses such as nutritive value and voluntary intake. Methods that are capable of characterizing forage quality through the physical resistance to degradation have been proposed, including grinding resistance and shearing resistance. Canonical correlations establish a multivariate approach associating multiple variables depicting interrelations studies between groups of dependent and independent variables. The objective of this research was to assess the degree of association among groups of quality-related responses of grazed Xaraés palisadegrass forage using canonical correlations among morphological, chemical and physical characteristics of forage samples. Only the first canonical pair was significant in the correlation between the morphological and physical variables. Between morphological and chemical variables, none of the canonical pairs were significant. In the canonical correlation between physical and chemical variables, the only significant canonical pair was the first, where forage with lower shearing resistance of leaves and stems, had higher concentration of crude protein in leaves and whole forage, lower concentration of neutral detergent fiber in leaves and whole forage, and higher digestibility of leaves and stems. The study of canonical correlations allowed to explain the relation between groups of qualitative variables of grazed Xaraés palisadegrass, and is highly significant between morphological and physical variables, and between physical than chemical variables.
\end{abstract}

Key words: Warner-Bratzler, digestibility, forage quality, nutritive value

\section{CORRELAÇÕES CANÔNICAS ENTRE CARACTERÍSTICAS MORFOLÓGICAS, FÍSICAS E BROMATOLÓGICAS DO CAPIM XARAÉS SOB PASTEJO ROTATIVO}

\begin{abstract}
RESUMO: Em experimentos de avaliação de forrageiras muitas vezes são priorizadas as análises de adaptação e produtividade e posteriormente parâmetros de valor nutritivo e consumo. Através de estudos para melhor caracterizar a qualidade de forrageiras por meio de sua resistência física foram propostas técnicas tais como a resistência à moagem e a resistência ao cisalhamento. Análise de correlação canônica é uma abordagem estatística sobre múltiplas variáveis que facilita o estudo de inter-relações entre grupos de variáveis dependentes e independentes. O objetivo desta pesquisa foi avaliar o grau de associação entre grupos de respostas qualitativas da forragem do capim Xaraés sob pastejo utilizando correlações canônicas entre características morfológicas, bromatológicas e físicas de amostras de forragem. Apenas o primeiro par canônico foi significativo na correlação entre variáveis morfológicas e físicas. Na análise de correlação canônica entre variáveis morfológicas e bromatológicas, nenhum dos pares canônicos foi significativo. Na correlação canônica entre variáveis físicas e bromatológicas, apenas o primeiro par foi significativo, onde forragem com menor resistência ao cisalhamento de colmos e folhas, possui maior concentração de proteína bruta (PB) nas folhas e na forragem íntegra, menores concentrações de fibra em detergente neutro (FDN) nas folhas e na forragem íntegra e alta digestibilidade de folhas e colmos. O estudo de correlações canônicas permitiu explicar a relação entre grupos de variáveis qualitativas do capim
\end{abstract}


Xaraés sob pastejo, e é significativa entre variáveis morfológicas e físicas, e entre físicas versus bromatológicas.

Palavras-chave: Warner-Bratzler, digestibilidade, qualidade de forragem, valor nutritivo

\section{INTRODUCTION}

The assessment of adaptive and productive characteristics of genotypes is generally prioritized over qualitative responses such as nutritive value and voluntary intake, when forages are evaluated. As a result, plant materials can be discarded early into the screening process if they are deemed not highly productive, despite having good qualitative characteristics. In addition, released cultivars may be adopted by producers before their qualitative characteristics in response to management are fully known (Euclides et al., 2000). Xaraés palisadegrass [Brachiaria brizantha (Hochst ex A. RICH.) STAPF. cv. Xaraés] was released as a promising forage grass for the Brazilian beef cattle industry, but its productive and qualitative characteristics in response to a range of defoliation managements are still unknown.

Methods that are capable of characterizing forage quality through the physical resistance to degradation have been proposed, including grinding resistance (Minson \& Cowper, 1974) and shearing resistance (Mackinnon et al., 1988). There is evidence that resistance to shearing is correlated with digestibility and chemical composition, especially the proportion of cell wall components in the forage (Wilson, 1997; Hughes et al., 2000). Other forage chemical constituents are thought to be correlated with the ease of degradation in the rumen, but the relative contribution of individual constituents to particle size reduction is not well understood.

Canonical correlations describe the relationship between metric independent variables and multiple dependent measures (Hair et al., 1998). This technique is often used in exploratory studies where out of a large number of variables, the researcher may be interested in examining only a few linear combinations within the set (Trugilho et al., 2003). It is possible, then, to study these linear combinations and to identify which correlations are higher within a pool of associated responses. An important characteristic in canonical correlation analyses is that, in contrast with principal components analysis, the magnitude of the variables is not important. In addition, canonical correlations analysis is a technique in which derived variables are obtained from two sets of original variables whereby the correlations between corresponding derived variables are maximized (Revell \& Harrison, 2008). The correlation does not stop at the derivation of a simple relation be- tween groups of variables, and several canonical functions (canonical pairs) can be derived for other studies involving the same variables (Padula, 2002).

The objective of this research was to assess the degree of association among groups of quality-related responses of grazed Xaraés palisadegrass forage using canonical correlations among morphological, chemical and physical characteristics of forage samples.

\section{MATERIAL AND METHODS}

The experiment was carried out in Piracicaba, São Paulo state, Brazil $\left(22^{\circ} 42^{\prime}\right.$ S, $47^{\circ} 30^{\prime} \mathrm{W}, 580 \mathrm{~m}$ above sea level). The experimental design was completely randomized, with three treatments corresponding to three grazing strategies, which were defined either by light interception (LI) by the canopy (grazing started with $95 \%$ LI or $100 \% \mathrm{LI}$ ) or based on chronological time (grazing started every 28 days). Postgraze stubble was $15 \mathrm{~cm}$, and each treatment was replicated three times.

Measurements of light interception and sward height were taken every regrowth, initiating immediately after grazing, at increments of $10 \mathrm{~cm}$ on sward height and immediately before the next grazing, in order to characterize the structural variations of the sward.

Once swards were conditioned to their respective grazing schedules forage samples were collected immediately before each grazing. Within each paddock, sites (15-20) were selected at random and handplucked samples were collected above the $15 \mathrm{~cm}$ stubble and taken to the laboratory. Each composite sample, weighing approximately $2 \mathrm{~kg}$ (fresh forage), was then separated and a sub-sample of $700 \mathrm{~g}$ (unprocessed) was oven-dried at $65^{\circ} \mathrm{C}$ to constant weight (48-72 h). The remaining material (approximately 1.3 $\mathrm{kg}$ ) was separated in its morphological components (green stems, green leaves and dead material). The dead material was directly taken into the oven and dried at $65^{\circ} \mathrm{C}$ to constant weight. From the leaf fraction another sub-sample was taken, including leaves of all categories (young to mature) for a total of 20 leaves. Shear resistance of these leaf blades was measured in a Warner-Bratzler Meat Shear at the midpoint of their length. The same procedure was followed for the stem fraction. The sheared material was subsequently returned to their respective sub-samples and dried at $65^{\circ} \mathrm{C}$ to constant weight. 
Dried samples of leaves and whole forage were tested for grinding resistance. For that evaluation, these dried samples were first ground to pass a 5-mm screen. Then, $20 \mathrm{~g}$ of this material were ground again to pass a $1 \mathrm{~mm}$ screen for $25 \mathrm{~s}$. The ground material $(1 \mathrm{~mm})$ and the residue not ground of these sub-samples were then weighed. Grinding resistance was given as the proportion of the initial $20 \mathrm{~g}$ that did not pass the $1 \mathrm{~mm}$ screen. Thus materials with higher resistance to grinding were those where the $5 \mathrm{~mm}$ residue (unground to $1 \mathrm{~mm}$ ) was higher (Hughes et al., 1998).

All dried samples were subsequently ground in a Wiley mill with $1 \mathrm{~mm}$ screen and taken to the laboratory for chemical analyses. Crude protein $(\mathrm{CP})$ concentration was determined using the Dumas combustion method, with a LECO FP-528 automatic nitrogen (N) analyzer (Wiles et al., 1998). In vitro dry matter digestibility (IVDMD) was determined by the ANKOM Fiber Analyzer (ANKOM Technology Corporation, Fairport, NY) protocol described by Holden (1999). The results were atypically high and a correction factor was applied after the analysis of IVDMD by the Tilley \& Terry (1963) method in half of the samples. The correction factor was given by the equation $\mathrm{y}=27.4193+(0.055061 \mathrm{x})$ where $\mathrm{x}$ is the value of the corrected digestibility and $y$ is the value of the digestibility found by the ANKOM method. Concentrations of neutral detergent fiber (NDF) and acid detergent fiber (ADF) were determined using the sequential method of the ANKOM Fiber Analyzer (ANKOM Technology Corporation, Fairport, NY), described by Holden (1999). Lignin (LIG) concentration was determined by the method described by Soest et al. (1991).

Canonical correlations among the groups of morphological variables ( $\%$ leaves, $\%$ stems and $\%$ dead material), chemical composition responses (concentrations of $\mathrm{CP}, \mathrm{NDF}, \mathrm{ADF}$, in vitro digestible dry matter, and LIG) and physical characteristics (grinding resistance and shear resistance) were established using PROC CANCORR of SAS (SAS Institute, 1989), after pooling all treatments, replications and sampling dates together. Because the number of sampling dates varied across treatments (four, five, or six, depending on treatment) not all observations were used in generating the correlation parameters. For example, the $100 \%$ LI treatment had only four sampling dates due to the longer intervals between grazings. Thus, data corresponding to cycles 5 and 6 in this treatment were considered missing data in the analysis. Therefore, the total number of samples (n) used in the correlation study was 45. For each correlation, three pairs of canonical variables were established using a 5\% level of significance. Canonical coefficients were considered significant when higher than 0.30 following the Wilks' Lambda statistic.

\section{RESULTS AND DISCUSSION}

The descriptive statistics for all response variables studied are shown in Table 1. The first canonical correlation studied was between the group of morphological and physical variables (Table 2). Due to the small amount of stems above the $15 \mathrm{~cm}$ stubble it was not possible to measure the grinding resistance of stems. Only the first canonical pair was significant $(\mathrm{r}=0.4939 ; p=0.0295)$, and thus the only pair that was interesting to the study. As mentioned earlier, only the canonical coefficients that were higher than 0.30 were considered significant (Harris, 1975) and even so, only to establish the significance of the relative contribution of the canonical variables in the relationships between the two sets of variables being examined. Thus, when the canonical coefficient associated with its variables is significant, this variable is said to participate in the dimension of relations between the two sets studied, and corresponds to the pair of canonical functions discussed. Either the variable interferes or is participating in the relations between the two sets analyzed. As a consequence, samples with higher proportion of leaves tended to have lower shearing resistance of leaves and stems, and higher grinding resistance of whole forage. On the other hand, samples with higher proportion of stems had also higher proportion of dead material, higher shearing resistance of leaves and stems, and lower grinding resistance of leaves (Table 3). The canonical coefficients related to the grinding resistance variables $(0.2758$ and 0.3814$)$ seem to be somewhat contradictory to the other physical variables (shearing resistance). One possible explanation is the lack of differences in grinding resistance.

The second canonical correlation studied was between the group of morphological and chemical variables (Table 3). Due the fact that some samples resulted in a small amount of stems above $15 \mathrm{~cm}$, it was not possible to run the chemical analyses for all experimental units. The canonical correlation analysis is not compatible with this, and therefore the chemical variables considered were only those from complete the data set.

In the canonical analysis between morphological and chemical variables, none of the canonical pairs were significant, with $p=0.1349$ for the first one, $p=0.2998$ for the second and $p=0.5380$ for the third. No canonical correlations could be established with this data set between these groups of variables.

The third canonical correlation was between physical and chemical variables (Table 4). The only significant canonical pair was the first $(p=0.0001)$, and this was, therefore, the only pair studied. In this pair forage with lower shearing resistance of leaves and stems, had higher concentration of CP in leaves and 
Table 1 - Descriptive statistics of the response variables used in the correlation study.

\begin{tabular}{|c|c|c|c|c|}
\hline Variable & Mean & Standard error & & \\
\hline$\%$ Leaves & 90.1 & 0.6 & 81.9 & 95.9 \\
\hline$\%$ Stems & 7.8 & 0.6 & 2.5 & 16 \\
\hline \% Dead Material & 2.1 & 0.2 & 0 & 5.1 \\
\hline SR Leaves & 4.3 & 0.1 & 3.0 & 5.7 \\
\hline SR Stems & 10.2 & 0.3 & 7.0 & 13.3 \\
\hline GR Leaves & 3.8 & 0.1 & 2.7 & 5.4 \\
\hline GR Whole Forage & 3.6 & 0.1 & 2.8 & 5.2 \\
\hline IVDMD Leaves & 68.5 & 0.3 & 64.4 & 71.4 \\
\hline IVDMD Whole Forage & 69.4 & 0.2 & 65.4 & 72.3 \\
\hline IVDMD Stems & 65.2 & 0.4 & 59.2 & 70.1 \\
\hline CP Leaves & 13.2 & 0.4 & 7.5 & 17.3 \\
\hline CP Whole Forage & 12.6 & 0.4 & 7.4 & 17.5 \\
\hline NDF Leaves & 68.2 & 0.4 & 63.9 & 73.9 \\
\hline NDF Whole Forage & 68.4 & 0.4 & 63.7 & 72.8 \\
\hline ADF Leaves & 35.2 & 0.3 & 31.6 & 39.9 \\
\hline ADF Whole Forage & 35.3 & 0.3 & 31.8 & 38.5 \\
\hline LIG Leaves & 3.7 & 0.04 & 3.3 & 4.8 \\
\hline LIG Whole Forage & 4.3 & 0.1 & 3.6 & 5.3 \\
\hline
\end{tabular}

$\mathrm{SR}=$ Shearing Resistance GR $=$ Grinding Resistance IVDMD $=$ In Vitro Dry Matter Digestibility $\mathrm{CP}=$ Crude Protein; $\mathrm{NDF}=$ Neutral Detergent Fiber; ADF $=$ Acid Detergent Fiber; LIG $=$ Lignin.

Table 2 - Canonical correlations and canonical variables between the group of morphological (\% leaves, \% stems and \% dead material) and physical variables (shearing resistance of leaves and stems, grinding resistance of leaves and whole forage), in grazed Xaraés palisadegrass.

\begin{tabular}{|c|c|c|c|}
\hline \multirow{2}{*}{ Variable } & \multicolumn{3}{|c|}{ Canonical Variables } \\
\hline & $1^{\text {st }}$ pair $*$ & $2^{\text {nd }}$ pair $*$ & $3^{\text {rd }}$ pair $*$ \\
\hline$\%$ Leaves & 0.4846 & -0.0402 & -0.0568 \\
\hline$\%$ Stems & -0.4462 & 0.0845 & 0.1285 \\
\hline$\%$ Dead material & -0.4311 & -0.0877 & -0.1505 \\
\hline SR Leaves & -0.3810 & -0.0117 & 0.1124 \\
\hline SR Stems & -0.4011 & -0.0800 & 0.1891 \\
\hline GR Leave & 0.2758 & 0.3062 & 0.0782 \\
\hline GR Whole forage & 0.3814 & -0.0660 & 0.2049 \\
\hline r (Canonical correlations) & 0.4939 & 0.3865 & 0.3484 \\
\hline * $p$ (Canonical variables) & 0.0295 & 0.0705 & 0.0752 \\
\hline Proportion & 0.5070 & 0.2760 & 0.2171 \\
\hline
\end{tabular}

$* p<0.05 . \mathrm{SR}=$ Shearing Resistance; $\mathrm{GR}=$ Grinding Resistance.

whole forage, lower concentration of NDF in leaves and whole forage, and higher IVDMD of leaves and stems.

Until recent years, canonical correlation analysis was a relatively unknown statistical technique. As with almost all of the multivariate techniques, the availability of computer programs has facilitated its increased application to research problems (Hair et al., 1998). For example, it can be valuable in plant breeding and screening, where canonical correlations can direct the material selection for variables that are too difficult or too expensive to measure in high quantities, by finding other variables that can be easily measured or that require less resources to quantify. Butt et al. (2007), found effectiveness of canonical analysis as a multivariate technique to determine biochemical and quality parameters of dietary fiber. The analysis revealed high correlation between the quality characteristics and the other components. 
Table 3 - Canonical correlations and canonical variables between the group of morphological (\% leaves, \% stems and $\%$ dead material) and chemical ( $\mathrm{CP}$ in leaves and whole forage, NDF in leaves and whole forage, ADF in leaves and whole forage, LIG in leaves and whole forage, and IVDMD of leaves, stems and whole forage) in grazed Xaraés palisadegrass.

\begin{tabular}{|c|c|c|c|}
\hline \multirow{2}{*}{ Variable } & \multicolumn{3}{|c|}{ Canonical Variables } \\
\hline & $1^{\text {st }}$ pair $*$ & $2^{\text {nd }}$ pair $*$ & $3^{\text {rd }}$ pair $*$ \\
\hline$\%$ Leaves & 0.6358 & 0.0311 & -0.0475 \\
\hline$\%$ Stems & -0.5977 & -0.1177 & 0.1317 \\
\hline$\%$ Dead material & -0.5333 & 0.2082 & -0.1875 \\
\hline CP Leaves & 0.3376 & 0.0599 & 0.2469 \\
\hline CP Whole forage & 0.4515 & 0.0559 & 0.1574 \\
\hline NDF Leaves & -0.3723 & -0.2249 & 0.0177 \\
\hline NDF Whole forage & -0.4214 & -0.2093 & -0.0338 \\
\hline ADF Leaves & -0.1921 & -0.1163 & 0.1178 \\
\hline ADF Whole forage & -0.3368 & 0.0937 & -0.0214 \\
\hline LIG Leaves & -0.0059 & 0.0828 & -0.0209 \\
\hline LIG Whole plant & -0.0420 & -0.0869 & -0.1139 \\
\hline IVDMD Leaves & 0.1284 & 0.0885 & 0.0890 \\
\hline IVDMD Whole forage & 0.2099 & -0.0102 & 0.0782 \\
\hline IVDMD Stems & 0.1786 & 0.3602 & 0.1251 \\
\hline r (Canonical correlations) & 0.6404 & 0.5825 & 0.4435 \\
\hline$* p$ (Canonical variables) & 0.1349 & 0.2898 & 0.5380 \\
\hline Proportion & 0.4782 & 0.3533 & 0.1685 \\
\hline
\end{tabular}

${ }^{*} p<0.05 . \mathrm{CP}=$ Crude Protein; NDF $=$ Neutral Detergent Fiber, $\mathrm{ADF}=$ Acid Detergent Fiber, LIG $=$ Lignin, IVDMD $=$ In Vitro Dry Matter Digestibility.

Table 4 - Canonical correlations and canonical variables between physical (shearing resistance of leaves and stems, grinding resistance of leaves and whole forage) and chemical (CP in leaves and whole forage, NDF in leaves and whole forage, $\mathrm{ADF}$ in leaves and whole forage, LIG in leaves and whole forage, and IVDMD of leaves, stems and whole forage) in grazed Xaraés palisadegrass.

\begin{tabular}{lccc}
\hline \multirow{2}{*}{ Variable } & & Canonical Variables \\
\cline { 2 - 3 } & $1^{\text {st }}$ pair $*$ & $2^{\text {nd }}$ pair $*$ & $3^{\text {rd }}$ pair $^{*}$ \\
\hline SR Leaves & -0.6966 & 0.3083 & 0.0938 \\
SR Stems & -0.7810 & 0.1364 & 0.1916 \\
GR Leaves & 0.6244 & -0.0802 & 0.3785 \\
GR Whole forage & 0.5842 & 0.3726 & 0.1061 \\
CP Leaves & 0.8089 & -0.0813 & -0.1311 \\
CP Whole forage & 0.7953 & 0.1310 & 0.0530 \\
NDF Leaves & -0.3734 & -0.0412 & 0.2116 \\
NDF Whole forage & -0.5055 & -0.2317 & 0.1033 \\
ADF Leaves & 0.0400 & -0.0367 & 0.1308 \\
ADF Whole forage & -0.1834 & -0.2170 & 0.0807 \\
LIG Leaves & 0.0175 & -0.2236 & 0.1104 \\
LIG Whole forage & 0.1305 & -0.0093 & -0.2123 \\
IVDMD Leaves & 0.3650 & 0.0193 & -0.0306 \\
IVDMD Whole forage & 0.1491 & 0.1846 & 0.0996 \\
IVDMD Stems & 0.5161 & 0.1180 & -0.3280 \\
r (Canonical correlations) & 0.8868 & 0.6112 & 0.5760 \\
$* p$ (Canonical variables) & 0.0001 & 0.3297 & 0.5822 \\
Proportion & 0.7633 & 0.1236 & 0.1029 \\
\hline
\end{tabular}

$* p<0.05 . \mathrm{SR}=$ Shearing Resistance, $\mathrm{GR}=$ Grinding Resistance, $\mathrm{CP}=$ Crude Protein, $\mathrm{NDF}=$ Neutral Detergent Fiber, ADF $=$ Acid Detergent Fiber, LIG = Lignin, IVDMD = In Vitro Dry Matter Digestibility. 


\section{CONCLUSIONS}

Canonical correlations are good estimators of the relationships between groups of qualitative variables of grazed Xaraés palisadegrass, and are highly significant between morphological and physical variables, and between physical and chemical variables.

\section{ACKNOWLEDGEMENTS}

Thanks are due to FAPESP for granting a graduate scholarship to the first author.

\section{REFERENCES}

BUTT, M.S.; SHAHZADI, N.; SHARIF, M.K.; NASIR, M. Canonical correlation: a multivariate technique to determine the contribution of various dependent and independent variables. International Journal of Food Science and Technology, v.42, p.1416-1423, 2007.

EUCLIDES, V.P.B.; CARDOSO, E.G.; MACEDO, M.C.M.; OLIVEIRA, M.P. Consumo voluntário de Brachiaria decumbens cv. Basilisk e Brachiaria brizantha cv. Marandu sob pastejo. Revista Brasileira de Zootecnia, v.29, p.2200-2208, 2000.

HAIR, J.F; ANDERSON, R.E; TATHAM, R.L; BLACK, W.C. Multivariate data analysis. 5 ed. Englewood Cliffs: PrenticeHall, 1998. 730p.

HARRIS, R.J. A primer of multivariate statistics. New York: Academic Press, 1975. 332p.

HOLDEN, L.A. Comparison of methods of in vitro of dry matter digestibility for ten feeds. Journal of Dairy Science, v.82, p.1791-1794, 1999.

HUGHES, R.G.; VALLE, C.B.; SABATEL, V.; BLOCK, J.; JESSOP, N.S.; HERRERO, M. Shearing strength as an additional selection criterion for quality in Brachiaria pastures ecotypes. Journal of Agricultural Science, v.135, p.123-130, 2000.

HUGHES, R.G.; VALLE, C.B.; HERRERO, M. Estimativa de resistência ao cisalhamento e à moagem em quatro espécies de Brachiaria. In: REUNIÃO ANUAL DA SOCIEDADE BRASILEIRA DE ZOOTECNIA, 35., Botucatu, 1998. Anais. Botucatu: SBZ, 1998. p.43-45.
MacKINNON, B.W.; FESTON, H.S.; BARRY, T.N.; SEDCOLE, J.R. The effect of reduced leaf shear strength the nutritive value of perennial ryegrass. Journal of Agricultural Science, v.3, p.469-474, 1988.

MINSON, D.J.; COWPER, J.L. An integrating wattmeter for measuring the energy used to grind pasture samples. Journal of the British Grassland Society, v.29, p.133-135, 1974.

PADULA, F.R.G. Contribuição à análise de especificações de componentes de rodovias e melhoria de qualidade de viagens. São Carlos: USP/EESC, 2002. 126p. (Doutorado).

REVELL, L.J.; HARRISON, A.S. PCCA: a program for phylogenetic canonical correlation analysis. Bioinformatics, v.4, p.1018$1020,2008$.

SAS INSTITUTE. SAS/STAT user's guide: version 6.4 ed. Cary: SAS Institute, 1989. v.2, 846p.

SOEST, P.J van; ROBERTSON, J.B., LEWIS, B.A. Methods for dietary fiber, neutral detergent fiber, and non starch polysaccharides in relation to animal nutrition. Journal of Dairy Science, v.74, p.3583-3597, 1991.

TILLEY, J.M.A.; TERRY, R.A. A two-stage technique for the in vitro digestion of forage crops. Journal of the British Grassland Society, v.18, p.104-111, 1963.

TRUGILHO, P.F.; LIMA, J.T.; MORI, F.A. Correlação canônica das características químicas e físicas da madeira de clones de Eucalyptus grandis e Eucalyptus saligna. Revista Cerne, v.9, p.66-80, 2003.

WILES, P.G.; GRAY, I.K ; KISSLING, R.C. Routine analysis of protein by Kjeldahl and Dumas methods: review and interlaboratory study using dairy products. Journal of AOAC International, v.81, p.620-632, 1998.

WILSON, J.R. Structural and anatomical traits of forage influencing their nutritive value for ruminants. In: SIMPÓSIO INTERNACIONAL SOBRE PRODUÇÃO ANIMAL EM PASTEJO, Viçosa, 1997. Anais. Viçosa: UFV, 1997. p.173208.

Received September 24, 2007

Accepted July 25, 2008 